Article

\title{
How to Lead the Board of Directors to a Sustainable Development of Business with the CSR Committees
}

\author{
Francesca Gennari \\ Department of Economics and Management, University of Brescia, via S. Faustino 74/b, 25122 Brescia, Italy; \\ francesca.gennari@unibs.it
}

Received: 29 October 2019; Accepted: 3 December 2019; Published: 7 December 2019

check for updates

\begin{abstract}
The sustainable development of business requires adjustments in corporate governance to assure the economic, social and environmental aspects of a firm's responsibility are managed according to the triple bottom line approach. For this purpose, the board of directors can establish devoted corporate social responsibility (CSR) committees to reduce a company's exposure to responsibility failures. By means of a quantitative analysis on listed firms on FTSE MIB and STAR markets of the Italian Stock Exchange and embracing different theories this paper aims at finding the potential influence of external (soft law and socio-environmental industry risk) and internal (firm size and ownership structure) factors on the presence of CSR committees. This study contributes to the existing literature about sustainability in business, recommends to directors to not underestimate the risk of 'strategic unsustainability', and offers to regulators significant food for thought to improve the contribution to sustainable development by companies.
\end{abstract}

Keywords: corporate sustainability; CSR committees; corporate social responsibility; Italian stock exchange

\section{Introduction}

The awareness to deal with environmental and socio-economic problems emphasized by international organizations (e.g., United Nations Agenda 2030, the Green New Deal for Europe declared by the President of the European Commission in 2019) has highlighted the importance of firms involvement toward more sustainable business models and corporate social responsibility (CSR). Furthermore, the ethical issues related to corporate scandals of recent decades, due to a mismanagement by the board of directors (BoDs) aimed at favouring only certain categories of stakeholders, have stressed the need for a responsible business conduct and the institutionalization of business ethics within the BoDs.

Scholars have extensively studied the BoDs as a factor determining the level of corporate orientation towards social responsibility and sustainability [1,2]. Agency theory $[3,4]$ states that the BoDs, receiving a mandate by ownership to run the business, is responsible for the definition of company's goals which must be aligned with the agents' interests in order to mitigate the so called agency conflicts [5]. Mixing the agency theory with the stakeholder theory [6,7], the BoDs must be capable of managing the sustainable development of firm in the long-run by a corporate global responsibility towards stakeholders (shareholders included), overcoming the emphasis on the relationship between company and its shareholders. This can be achieved by the BoDs defining corporate strategies and policies along the so-called 'triple bottom line', namely the equilibrium among economic, social and environmental performance [8]. This sustainability approach is oriented to guarantee the firm's competitive lost-lasting advantage, satisfying the expectations of wide stakeholders' groups, seizing opportunities and managing risk [9]. As well, international institutions have emphasized the 
importance of the commitment by the BoDs in terms of issues of CSR (e.g., the Resolution 2012/2098(INI) of 06/02/2013 by the European Parliament).

The attention for CSR has gradually led to the diffusion within the BoDs of special committees devoted to sustainability matters (CSR committees), rarely as a legal requirement and more frequently as a recommended self-discipline practice or autonomous corporate initiative. Such committees were born to manage ethics and environmental issues separately, but starting from the end of the first decade of the 2000s 'sustainability' becomes the most recurrent committees' name, emphasizing the acknowledgment of the relations among environmental and social responsibility [9].

Board committees, thanks to activities oriented to monitor, propose and give assurance to the board, manage issues related to critical success factors and/or source of potential conflicts of interest [10-12]. In particular, CSR committees are established to guarantee the protection of stakeholders in the case of competing interests, according to the goal to create shared value thanks to the coordination among economic, social and environmental dimensions [13,14]. In fact, a real corporate commitment in sustainability influences different firm's areas and processes (think, for example, to the circular economy, the integrated reporting, the opportunity to be listed in special sustainable stock exchange indexes) and, for this reason, it needs to be planned by the board according to a systemic perspective.

Many researches are about the relationship between corporate governance and CSR, considering that the board structure influences the triple bottom line performance [1,15-19], but mostly ignoring the role of CSR committees within the boards. Most of the previous researches studied the CSR committees as determinants of corporate performance [13,20-25] and corporate disclosure [26] instead of as effects of internal or external variables $[9,27]$.

This gap in the literature and the spreading importance of managing sustainability as strategic issue at the board level suggest us to go in-depth and debate this matter.

This paper, embracing both the institutional theory [28-31] and the resource based theory [32-34], by means of a regression analysis, aims at underling the potential influence of both external (soft law and industry risk) and internal (firm's size and ownership structure) factors on CSR committees.

This paper contributes to the existing literature about the board's committees and sustainability, encouraging to consider the impacting factors on CSR committees in addition to the impact of such committees on corporate social and environmental performance.

Furthermore, this study contributes to the commitment of private sector in the global sustainable development, suggesting firms to include sustainability in the board's strategic discussions to ensure the business strategies are respectful of the environmental and social matters. In fact, the institutionalization of these issues in strategies is the first step to create a real culture of sustainability within all the organization. This process can be led by CSR committees made up of board's members with specific skills and officially committed for sustainable business strategies. The management of CSR is becoming even more complicated because of the global engagement for a sustainable development requested by national and international institutions. For this reason, companies need to be aware of their role within the society and need corporate structure to reduce their exposure to responsibility failures and to handle complexity.

Finally, this paper can provide regulators to useful information for promoting special board structures helping firms to manage their sustainability strategies in a synergic way.

The article is organized as follows. First, we review the existing studies on CSR committees, to highlight what is known and potential gap; the literature review allows us to depict the theoretical framework for the hypotheses generation. Then, we formulate the hypotheses, the methodology is presented, as well as the results and discussion. Lastly, we conclude with theoretical, managerial and policy implications of our study, considering its limitations and opportunities for future research paths. 


\section{Literature Review and Theoretical Background}

\subsection{The Role of CSR Committees}

The environmental and social global problems (e.g., global warning, deforestation, pollution, water crisis, poverty, inequality, political instability), together with the concern that big scandals (as Enron, WorldCom, and Ahold) may happen again test the ability by firms to manage relations with broad categories of stakeholders. In fact, while some corporate failures are the result of fraudulent practices, many companies exhibit a real corporate governance risk related to conflicts of interest, inexperienced directors, excessive short-term orientation, and the scarce attention for social and environmental matters [35,36]. All these circumstances stressed the BoDs structure as a critical factor for a good corporate governance, respectful of the expectations of wide categories of stakeholders. Over the years, legislators, regulators, national and international institutions pointed their attention on the board composition (e.g., in terms of board independence, CEO duality, and board committees), as the corporate governance theories emphasized the BoDs structure as a determinant mechanism to develop firm's competitiveness and performance [37,38].

While some BoDs structural characteristics are mandatory (e.g., the establishment of the audit committee in the one-tier or unitary board systems, or the minimum number of independent directors depending on the firm size in the two-tier of dual board systems), others depends on the same BoDs choices (e.g., the establishment of nominating, compensation, and CSR committees).

Committee level researches are heavily focused on the benefits of audit, nomination and remuneration committees within the BoDs because of the high risks of conflicts of interest characterizing these areas. In fact, the key role played by the board committees is to manage potential conflicts of interest supporting the BoDs in its decision-making process [10,12,39,40]. Other ad-hoc committees for specific tasks can be established.

In particular, the literature about the board committees depicts a growing presence of CSR committees [13,41], with the aim to manage activities regarding social, environment, health and safety matters, and stakeholder relationships [42], balancing the potential conflict between shareholders' short term profit expectations and the long term creation of value as fundamental to corporate future life, as sustainability view suggests [43]. In fact, such committees act as mediators among conflicting interests within the board, or when short-termism demands conflict with the long-lasting value [44], reviewing and recommending to the BoDs goals and policies that maintain the company committed to high standards of ethics and integrity, legal compliance, social responsibility and sustainability.

As Purcell [45] remarks there are many reasons for the establishment of such committees: to account to stakeholders the structuring of ethical and sustainability issues, to spread the CSR culture throughout the organization, to strengthen the corporate legitimacy within the community.

The institutionalization of sustainability into the corporate goals thanks to the establishment of CSR committees can be a source of competitive advantage. In fact, according to the signaling theory [46], based on the information asymmetry between companies and their shareholders, the existence of CSR committees makes visible to financial markets a commitment for environmental and social issues which goes beyond mere legal compliance. Nowadays, institutional investors are increasingly looking to environmental, social, and governance (ESG) funds [47], using responsible investing criteria: The investments in ESG funds increased of $+25.2 \%$ from 2014 to 2016 (Bloomberg data). BlackRock, the world's largest asset manager, has just become a partner of Ellen MacArthur Foundation launching its first circular economy fund. Hence, ESG investors need to identify which companies may be best positioned to succeed in a sustainable world analyzing corporate reports but also corporate structure in terms of board composition and board committees.

\subsection{Theoretical Framework}

The literature review explains the establishment of CSR committees with the aim by the BoDs to improve environmental impacts $[22,25,37,48]$, voluntary CSR disclosure $[26,49-53]$ or corporate 
social performance in general [21,23,54-58]. So, many researches emphasize CSR committees as a characteristic of the board structure to improve the corporate governance and positively influence the corporate performance. According to authors who embrace the agency theory [3,4], the BoDs effectiveness depends on the ability by the board to control the agency problems guaranteeing better corporate performance, in the short as well as the long term. The difficulty by the BoDs to perform this fiduciary duty [59] has led some scholars to focus on the BoDs committees as potential sources for solving some deficiencies of the full corporate board [60]. Other authors refer to legitimacy theory [31] emphasizing the disclosure effects of the establishment of CSR committee for corporate legitimation to operate [49-53] or for the obtaining of sustainability reporting assurance [61,62].

Kolev et al [60] suggest studying unexplored areas about the BoDs committees, and revisit the topic with different approaches and theories. This paper suggests us to complete the existing approach embracing also the resource based theory [32-34] and the institutional theory [28-31], not considering the CSR committees as determinants of dependent variables (performance, disclosure, stakeholder engagement, etc.) but the results of internal and external pressures on the BoDs.

Resource based theory bases the source of competitive advantage in the resources system that firm can manage, giving importance to the internal variables. Board structure is itself a system of resources [63] appointed by the ownerships for managing the successful development of company. The BoDs structure expresses variables as the corporate identity and the ability to nurture relationships with stakeholders, as the presence of special CSR committees within the BoDs expresses the stage of sustainability commitment by the board [64]. So, corporate ownership, being tasked by the law with appointing the board members depending on their skills and competencies, qualifies as one of the internal pressures on the BoDs structure, being viewed as CSR committees antecedent $[28,58,65]$.

Institutional theory focuses on the external pressures to corporate governance structure $[28,66-68]$, being they coercive (formal constraints as rules, laws and regulations) or normative (informal constraints as practices and standards). The literature review highlights few studies about the adoption of institutional theory to explain the corporate structure with particular regard to CSR committees. For Vigneau et al. [69] the adoption of Global Reporting Initiative (GRI) standards is the factor influencing the management structure and the relate presence of CSR committees; Gennari and Salvioni [9] and García-Sánchez et al. [27] positively relate the CSR committees with the mandatory provisions about CSR information.

The gap in the existing literature currently focused on CSR committees as independent variable, and the suggestion to refer to different theories support our research question about the impact of the external and internal pressures on the BoDs' choice to establish CSR committees, and allow us to develop the following hypotheses.

\section{Hypotheses Development}

To find the external and internal variables with a possible impact on the establishment of CSR committees we have focused on those that have resulted to be relevant in the literature about the board structure and sustainability issues.

\subsection{External Pressures and Related Hypotheses}

With regard to the external pressures on the choice by the BoDs to define a special structure devoted to sustainability as CSR committee, a research by Gennari and Salvioni [9] highlighted that the most relevant impacting variable was a formal constraint, specifically the mandatory non-financial disclosure ex Directive 2014/95/UE, which obliges certain large undertakings and groups to disclose non-financial information. The authors have analyzed more than 22,000 boards of European companies from 2000 to 2016, assuming as dependent variable the number of CSR committees by country and as independent variables the international formal (non-financial Directive) and informal (UN Global Compact, OECD Guidelines, ISO:26000, National Action Plans, perceived country's level of corruption, and soft law recommending CSR committees) constraints. 
In this paper we focus on Italy, where the cited Directive is in force but where no duty to constitute CSR committees exists. In particular, we analyze different markets belonging to the Italian Stock Exchange, subject to the Italian Self-Discipline Code by Borsa Italiana. This Code is addressed to all listed companies, outlines principles of good corporate governance recommending behaviors, and depicts some best practices according to the comply or explain principle.

Since Nineties, following the example of the UK with the Cadbury Code, many share issuers, asset management companies, and politics promoted the drafting of self-discipline codes to spread high standards of corporate governance.

National self-discipline codes can be defined as soft law being tools of regulation that, compared to the hard law, are more flexible in both the regulatory design and sanction system [70,71]. In fact, a deviation by company from a soft rule is not really an infringement of a law, and stakeholders will consider from time to time giving trust and resources to the company. Furthermore, the flexibility of the soft law finds reason in the continuous changes of the economic and legislative environments where companies operate [72], suggesting new and relevant issues.

The cited research by Gennari and Salvioni [9] stated a positive, even if not relevant, relation between the soft law and the CSR committees. In this paper, starting from [9] that remains on the international level of analysis, we aim to go in depth the impact of the soft law at national level confirming or not the previous results. For this reason, we argue that the presence of a soft law (national self-discipline code) recommending CSR committees as a standard of good corporate governance has a positive influence on the corporate governance structure in terms of CSR committees.

Hypothesis 1 (H1). Soft law has a positive association with voluntary decision by the BoDs to constitute a CSR committee.

Industry is suggested by the existing literature as a driver for CSR [73], considering the different level of social and environmental risk related to different business sectors. Jo and $\mathrm{Na}$ [74] suggest a negative relation between CSR engagement and firm risk over the long term. Adopting an industry risk perspective [75,76] similar CSR practices can be explained by similar environmental conditions [77]. In particular, Young and Marais [78] tested the effect of the industry characteristics on CSR reporting, finding a positive relation between high-impact risk industries (according to FTSE4Goods Indices which distinguish different risk level regarding inclusion impacts, climate change impacts, bribery impacts and labor impacts) and CSR voluntary disclosure.

Black [79] affirms that the lower the industry risk is, the higher the level of social license to operate by company is. So, companies operating in industries characterized by a high level of risk need to set their corporate governance with a special attention to CSR, considering also that CSR risk literature suggests the firm's risk decrease thank to the engagement in social responsibility [80,81]. Some authors emphasize the importance to manage the risk at the board-level with devoted positions which can be a single committee, a group of committees, or a Chief Risk Officer having a high level of technical expertise [82,83].

The adoption of a sustainability approach by business, as the one embraced in this paper, implies to consider adequately the sources of sustainability risk inherent to industry activities (e.g., water consumption, dangerous emissions, waste, and so on) and to assure their management as a strategic imperative. These considerations suggest us to formulate the following hypothesis.

Hypothesis 2 (H2). Industry risk has a positive association with voluntary decision by the BoDs to constitute a CSR committee.

\subsection{Internal Pressures and Related Hypotheses}

The positive effect of sustainable strategies on corporate revenues is proved by researches [84-87]. We adopt a different point of view, according to the resource based theory, using revenue as a proxy for 
firm size [88]. In fact, in the accounting researches the firm size is used to explain differences in corporate disclosure supporting a positive relations between the firm size and the level of voluntary disclosed non-financial information [89,90]. As literature suggests [9], non-financial reporting needs can lead the establishment of CSR committee; for this reason, we argue such committees are positively related with the voluntary disclosure about social and environmental business sphere, this last depending on the firm size. Furthermore, the greater the firm is, the higher its visibility is and the categories of stakeholders which can have socio-environmental interests toward it are wider [91]. For this reason, we assume that:

Hypothesis 3 (H3). Firm size has a positive association with voluntary decision by the BoDs to constitute a CSR committee.

The different mix of corporate ownership can have a relevant influence on corporate governance because of the same ownership appoints the directors who are responsible for the definition of business strategies and the management of corporate resources [92]. Hence, the BoDs is the expression of the ownership structure [12,16,18,19].

Previous researches highlighted different approach toward the BoDs sustainability commitment depending on the ownership characteristics [93], because different owners are characterized by different goals, and time horizons being interested in longer or shorter-term investments, and different risk exposures [94-98].

There are arguments supported by the literature review about the relation between sustainability and concentrated ownership by family, state and institutional investors. Ownership structure and CSR have been widely examined [26,99-104]. As regards to families, previous studies stated that when family owners, control, or manage the business a positive relation with social and environmental performance [105] is proved, as well as there are some research findings suggesting a negative relation [106-108]. State ownership seems to have a positive relation on sustainability report quality [109] and, accordingly on sustainability approach by managers, with particular regard to environmental issues. Alda [110] found a positive influence on ESG (Environmental, Social, Governance) performance by large pension-fund shareholding. Salvioni and Gennari [92], analyzing some of the most sustainable corporations in the world, assert that owner families and institutional investors possessing important percentage of share tend to give to decision-making processes a long-term sustainable approach. Considering these arguments, we formulate that:

Hypothesis 4 (H4). Relevant quota of concentrated ownership have a positive association with voluntary decision by the BoDs to constitute a CSR committee.

\section{Methodology}

We aim at testing the four hypotheses by means of a quantitative model that considers the impact of self-discipline Code's recommendation (soft law), industry risk level, revenue (as proxy of the firm size) and ownership concentration on the presence of CSR committees within the BoDs of Italian companies listed on FTSE MIB and STAR indexes of the Italian Stock Exchange (www.borsaitaliana.it). All the data have been collected from August and September 2019.

\subsection{Sample}

The Report on Corporate Governance of the Italian listed companies by Consob (2018), starting from 2017 (date when the L.D. n. 254/2016, which has transposed in the Italian law the Directive 2014/95/UE, entered into force) highlights that about $20 \%$ of the companies (representing the $61 \%$ of market capitalization) have instituted a sustainability committee. 
The total starting population of our analysis is composed of 40 companies listed on FTSE MIB index and 79 companies listed on STAR index. These companies are the ones listed on the two cited indexes at the date of the analysis; this number can change because of new entry and delisting during the year. We collected data by Bureau van Dijk Orbis Database, which contains information on companies across the world. Where the information was not available in the Database, we referred to companies' website. We removed companies missing information necessary in order to carry out our analysis including companies without an assigned level of industry risk because defined unethical (producers of arms and military equipment, producers of tobacco and hard liquor, casinos and other gambling facilities) by the European Bank for Reconstruction and Development (EBRD). We obtained 39 companies listed on FTSE MIB and 66 on STAR (Appendix A).

\subsection{Model and Measurement of Variables}

The dependent variable is the company's choice to establish a devoted committee for sustainability issues, and it is equal to 1 if firm has this committee, otherwise, it is 0 (Table 1 ). We consider 0 also the situations characterized by the other committees with tasks in social and environmental matters; in fact, the CSR committee's activities can be integrated into the audit or remuneration committees' tasks or delegated to organizational functions outside the BoDs.

Table 1. Variables Used in the Model and their Measures.

\begin{tabular}{|c|c|c|c|c|}
\hline Variables & Description & Measurement & Source of Data & $\begin{array}{c}\text { Expected Relation } \\
\text { between Independent } \\
\text { and Dependent } \\
\text { Variables }\end{array}$ \\
\hline CSR committee & $\begin{array}{l}\text { Dependent } \\
\text { variable }\end{array}$ & $0:$ no; 1: yes & Corporate website & \\
\hline Soft law & $\begin{array}{l}\text { Independent } \\
\text { variable }\end{array}$ & $0:$ no; 1 : yes & $\begin{array}{c}\text { Stock Market } \\
\text { Regulators }\end{array}$ & + \\
\hline Industry Risk Level & $\begin{array}{l}\text { Independent } \\
\text { variable }\end{array}$ & $\begin{array}{l}\text { 1: low risk level } \\
\text { 2: medium risk level } \\
\text { 3: high risk level }\end{array}$ & $\begin{array}{l}\text { Orbis Database, } \\
\text { EBRD List }\end{array}$ & + \\
\hline Revenue & $\begin{array}{l}\text { Independent } \\
\text { variable }\end{array}$ & $\mathrm{N}>0$ & Orbis Database & + \\
\hline $\begin{array}{l}\text { Ownership } \\
\text { concentration }\end{array}$ & $\begin{array}{l}\text { Independent } \\
\text { variable }\end{array}$ & $\begin{array}{c}\text { O1: } 1=3 \%<\mathrm{C} 1>24 \% \\
0=\text { Otherwise } \\
\text { O2: } 1=25 \%<\mathrm{C} 2>49 \% \\
0=\text { Otherwise } \\
\text { O3: } 1=\mathrm{C} 3>50 \% \\
0=\text { Otherwise }\end{array}$ & Orbis Database & + \\
\hline
\end{tabular}

For this aim we used content analysis [111,112] searching for committees called CSR or social (and synonymous), environmental, ethical (and synonymous), sustainability committees. A previous research on CSR committees in Europe [9] reveals that the name of such committees changed according to the public sensitivity for particular topics: until 2010 the term ethics/ethical prevailed to indicate the corporate need to obtain the legitimacy to operate. Furthermore, at the end of the first decade of the 2000s the concept of sustainability started to spread inducing also a change in the committees' name.

The Italian Self-discipline Code for listed companies updated 2018 recommends companies belonging to FTSE MIB, according to the comply or explain principle, to establish a devoted committee for sustainability matter and stakeholder relationships or to assess the possibility to manage these issues by other existing committees (art. 4). In fact, FTSE MIB index is the main benchmark index of the Italian stock markets. The FTSE MIB Index measures the performance of 40 Italian stocks capturing about the $80 \%$ of the internal market capitalization, and it is composed of companies of primary importance and high liquidity in different industries (www.borstaitaliana.it).

Although there is no a special statement for other indexes by market regulators, we consider in our analysis also the companies listed on STAR, because this segment includes medium-sized companies 
complying with the requirements of excellence in terms of high transparency in communication, high liquidity (free float of minimum 35\%), and corporate governance according to the highest international standards (mandatory audit and remuneration committees and top-level compensation linked to long term performance). The great attention for corporate governance by companies belonging to STAR induces us to argue a special attention for the BoDs composition aimed at reducing the risk of a business conduct inconsistent with the global responsibility towards stakeholders and the required standards. We consider the value 1 if a special recommendation to market exists and otherwise the value 0 (Table 1 ).

To assess the risk level, we refer to the Environmental and Social Risk Categorization List (revised 2014) by EBRD. It is a checklist addressed to financial institutions to assess the typical level of environmental and social risk related to particular business activities. The document by EBRD ranks business activities according to the EU statistical classification codes NACE Rev. 2 (Regulation (EC) No 1893/2006 of the European Parliament and of the Council). High risk activities are the ones characterized by a significant or long-term environmental and social risks and impacts. These business activities could obtain benefits by adopting a specialized risk assessment model. Medium activity risk refers to business activities with limited environmental and social risks and impacts; these business activities can prevent or mitigate the risks by means of technical and financial measures. Finally, activities characterized by a low level of risk have few environmental and social risk and impacts associated with them.

We collect by Orbis Database the matching code of each company searching in the EBRD list the corresponding risk level. The EBRD list expresses the risk level in a qualitative way (high, medium, low) using a scale based on three degree. For this reason, we attribute to each level a quantitative measure, identifying the low risk with 1 point, medium with 2 points, and high with 3 points of risk (Table 1).

As regard the firm operating revenue, that we considered as a proxy of firm size, we obtain data from Orbis Database expressed in USD (Table 1).

As for the ownership structure, Orbis Database gives us information about the direct participation (in \%) by the present shareholders. We measure the average value of ownership concentration according to three slots mentioned in the art.120 of Italian TUF, beyond which the communication requirements to Consob, that is the vigilance authority of Italian Stock Exchange, increase (3\%, 25\%, and $50 \%)$. The first slot is between $3 \%$ (the minimum level fixed to impose a duty to communicate) to $24 \%$; the second slot is between $25 \%$ and $49 \%$, and the third level is over $50 \%$ (Table 1 ).

To validate the hypotheses, we referred to a quantitative analysis using a multivariate regression built on the following model. Significance F supports the model.

$$
\text { CSR committee }_{i}=\beta_{0}+\beta_{1} \text { Soft Law }_{i}+\beta_{2} \text { Industry Risk Level }_{i}+\beta_{3} \text { Revenue }_{i}+\beta_{4} \mathrm{O} 1_{i}+\beta_{5} \mathrm{O} 2_{i}+\beta_{6} \mathrm{O}_{i}+\varepsilon_{i}
$$

\section{Results and Discussion}

Table 2 reports the descriptive statistics with reference to the variables used in the model. The size of firms belonging to different indexes is very different, as required by Borsa Italiana to be listed in either market. In fact, the average operating revenue of FTSE MIB is about 25 times the operating revenue of STAR market companies. Furthermore, the standard deviation is very relevant in FTSE MIB market signaling a strong difference in dimension of firms which capture the majority of the internal market capitalization.

More than half of the companies listed in FTSE MIB (58.97\%) have a CSR committee (it means that the Self-Discipline Code's recommendation is respected by one out of two companies), while little of the companies listed on STAR $(7.58 \%)$. The recommendation by Self-discipline code for Italian listed companies belonging to FTSE MIB to create a devoted committee for sustainability matters is partially performed. 
Table 2. Descriptive Statistics.

\begin{tabular}{ccccccccc}
\hline & \multicolumn{4}{c}{ FTSE MIB } & \multicolumn{4}{c}{ STAR } \\
\hline Variables & Min & Max & Mean & Std Dev & Min & Max & Mean & Std Dev \\
\hline CSR Committee & 0 & 1 & 0.590 & 0.498 & 0 & 1 & 0.076 & 0.267 \\
Soft law & 1 & 1 & 1 & 0 & 0 & 0 & 0 & 0 \\
Industry Risk Level & 1 & 3 & 1.615 & 0.747 & 1 & 3 & 1.697 & 0.632 \\
Revenue & 477,028 & $88,094,054$ & $14,447,690$ & $23,460,420$ & 8767 & $4,089,015$ & 577,627 & 696,157 \\
O1 & 0 & 1 & 0.590 & 0.498 & 0 & 1 & 0.788 & 0.412 \\
O2 & 0 & 1 & 0.205 & 0.409 & 0 & 1 & 0.303 & 0.463 \\
O3 & 0 & 1 & 0.410 & 0.498 & 0 & 1 & 0.470 & 0.503 \\
\hline
\end{tabular}

The industry risk does not show relevant differences in the analyzed markets; the average risk level is under the 2 points we have indicated as medium industry risk and the standard deviation is quite high for both markets.

As regard the ownership concentration, we can note the following situation: in the FTSE MIB market almost half of the capital stock belongs to small or to majority shareholders, while in the STAR market the allocation of ownership is more unbalanced on small stockholders, albeit with a relevant role of the biggest ones. The existence of owners belonging more than $50 \%$ of capital is a structural peculiarity of the insider systems of corporate governance (as Italy and most of the European countries) characterized by concentrated and commonly stable shareholding [44,92]. Please note that a company can have participation in different slots, that is the reason why adding up the averages for $\mathrm{O} 1, \mathrm{O} 2$ and O3 the total is more than $100 \%$.

Table 3. reports the bivariate correlation among the quantitative variables selected in the analysis, evidencing a series of low correlation coefficients among independent variables not exceeding the threshold limit of 0.90 [113], which is a signal of possible problems of multicollinearity. Table 4. reports the results obtained by the logistic regression model. ANOVA test supports the model significance $($ F-stat $=13.9681>$ F-crit $=2.2285)$.

Table 3. Bivariate Correlation.

\begin{tabular}{|c|c|c|c|c|c|c|c|}
\hline & $\begin{array}{c}\text { CSR } \\
\text { Committee }\end{array}$ & Soft Law & $\begin{array}{c}\text { Industry } \\
\text { Risk Level }\end{array}$ & Revenue & $\mathrm{C} 1$ & $\mathrm{C} 2$ & C3 \\
\hline CSR Committee & 1 & & & & & & \\
\hline Soft law & $0.5616^{*}$ & 1 & & & & & \\
\hline Industry risk level & 0.1069 & -0.0587 & 1 & & & & \\
\hline Revenue & 0.3392 * & 0.4287 * & -0.0426 & 1 & & & \\
\hline $\mathrm{O} 1$ & -0.1430 & $-0.2119^{* *}$ & -0.1256 & 0.1063 & 1 & & \\
\hline $\mathrm{O} 2$ & 0.0260 & -0.1070 & 0.0748 & -0.0110 & 0.2860 * & 1 & \\
\hline O3 & 0.1097 & 0.0578 & $0.2472 * *$ & -0.1280 & -0.6178 & -0.4995 & 1 \\
\hline
\end{tabular}

Table 4. Results from Regression Model.

\begin{tabular}{ccccc}
\hline & Coefficients & Standard Error & $t$-Stat & $p$-Value \\
\hline Constant $_{\text {Soft law }}^{*}$ & 0.0964 & 0.1547 & 0.6227 & 0.5349 \\
Industry risk level $^{*}$ & 0.4265 & 0.0881 & 4.8424 & $4.794 \times 10^{-6}$ \\
Revenue & 0.1114 & 0.0560 & 1.9900 & 0.0494 \\
O1 & $3.910 \times 10^{-9}$ & $2.5705 \times 10^{-9}$ & 1.5212 & 0.1314 \\
O2 & -0.1639 & 0.1075 & -1.5253 & 0.1304 \\
O3 & 0.0100 & 0.0966 & 0.1033 & 0.9179 \\
\hline
\end{tabular}

$* p<0.05$. 
The main objective of this study was to assess a possible pressure by external and internal variables on the establishment of CSR committees within the BoDs. The results show that a positive and significant variable is the Soft law, so we can accept H1. This supports the discussion about the role of the soft regulation in filling the vacuum left by the binding laws and contribute to the studies on corporate behavior regarding self-discipline codes' recommendations [114]. Galander et al. [70] state that firms' compliance to codes are positively influenced by a lively public debate about this issue.

A less relevant relation is between the industry risk and the presence of CSR committees within the boards, partially supporting H2. As OECD declares, listed companies are aware of the need to strengthen their risk management practices but they seem to give little importance to effectively do this [115]. Moreover, many scholars affirm the importance of industry characteristics for corporate behavior, in particular for responsibility disclosure [90], supporting their results with the consideration that 'sensitive' industries as regards social and environmental issues suffer more public pressures [116].

$\mathrm{H} 3$ is not supported, even if a weak positive relation is shown considering that some choices in terms of corporate governance structure could be expensive. This result is consistent with Prencipe [117]; this study is focused on Italy; it shows no effect of firm size on voluntary disclosure confirming that companies can voluntary limit their disclosure because of preparation costs. However, a comparative research by Fifka [90] highlights that, in general, firm size has a positive impact on responsible social behavior by companies (as voluntary disclosure) in both outsider and insider systems of corporate governance. So, this Italian peculiarity should be more studied.

Results do not support relations between different ownership characteristics and CSR committees, inducing us to exclude the hypothesis H4. This is consistent with a research which notes no effect of ownership characteristics on CSR with regard to Italy [117], but it does not fit with other studies regarding insider systems of corporate governance, as Germany, Italy and Sweden where ownership structure reveals no impact on social responsibility disclosure [118-120].

\section{Debate}

The purpose of this paper has been to study the effect of external and internal variables on the board structure in terms of the establishment of devoted CSR committees. Our starting point was the existing gap in the literature about this matter and the different approach previous studies have adopted considering CSR committees as the independent variable for corporate performance.

The analysis of 105 listed firms on Borsa Italiana in 2019 supports the influence of soft law on the choice by the BoDs to create a special group of directors officially committed in sustainability strategies. This result is consistent with other studies about the impact of soft regulation on CSR and suggests regulators to move forward in this direction. A less relevant impact is the one by the industry risk, while the other selected variables (firm size and ownership concentration) have not shown a relation with CSR committees, highlighting a phenomenon fit for more insights being in contrast with previous researches. This situation suggests scholars to go in depth the pressure on corporate governance structure considering the differences of countries defined as insider or outsider ones.

We acknowledge some limitations of this study. First, we limited our analysis on the Italian Stock Exchange considering the two most relevant markets for the purpose of this article. Future investigations could test the hypotheses on a larger scale, comparing insider systems of corporate governance, characterized by less developed financial markets and concentrated and stable shareholding, with outsider ones characterized by more developed financial markets and dispersed ownership that control the BoDs activities by means of the shares trade. Furthermore, our population was composed of listed companies at the date of the analysis. These limitations could be the starting points for future researches broadening the population and the period of observation to outline a multi-year trend.

Despite these limitations, this study can have theoretical and practical implications. The topic of CSR committees is not enough studied in corporate governance papers and the results are not always consistent. In this regard, this article fills a gap in the existing literature with a novel approach mixing different theories and discloses the benefits of CSR committees for a sustainable 
development of business, also opening a cultural debate about the way companies interpret the concept of sustainability as a joined mixture of economic, social and environmental responsibilities towards stakeholders. The corporate culture, defined as ways of thinking, values and beliefs that influence corporate behaviors [121] can be considered the real drive for the BoDs' strategies and goals being a critical element for the interaction with society and the optimization of global corporate performance [122]. According to this view, a real commitment in sustainability requires an appropriate corporate governance structure.

This article suggests listed companies particularly exposed to investors' assessments about their performance to do not underestimate the risk of 'strategic unsustainability' deriving from a scarce attention for sustainability at corporate governance level or from uncoordinated sustainable actions by different business units. This situation reduces the effectiveness and the efficacy of business strategies and can generate confusion within the company and from stakeholders point of view (e.g., reducing CSR to philanthropy or marketing). The inability to manage the socio-environmental issues together with the economic ones at the BoDs level can have immediate negative effects, as the freefall of stocks, and/or hard to measure future effects on corporate reputation and image. For these reasons, we suggest to listed companies to establish a CSR committee within the BoDs composed of a special group of expert directors in social and environmental matters. When this choice appears to be too much expensive for the company, it is important having in the lists of the candidates eligible for the BoDs' positions skills and competencies in sustainability management. Soft law and the corporate habit empower the audit committee with sustainability tasks; in this case companies should clearly report this choice to give evidence about their awareness to manage sustainability according to a risk based approach.

Furthermore, the Directive 2014/95/EU obliges certain large undertakings and groups to disclose non-financial information. Stakeholders, in particular the institutional investors, are pressing for a comparable social and environmental disclosure in order to properly assess different investment opportunities, and the efforts by Sustainability Accounting Standards Board (SASB) and Global Reporting Initiative (GRI) are moving in this directions. CSR committees, having a systemic vision of sustainability policies, can support the non-financial reporting process and work together with the investor relations function to comply with the law.

According to the results of this research about the effectiveness of the soft law, regulators should promote voluntary standards as regard sustainability disclosure and management also for smaller companies which are excluded from the hard law. Standards and guidelines are flexible instruments of soft regulation and they can be a stimulus to grow the awareness that sustainability is not a collection of isolated actions for the benefit of the environment or particular categories of stakeholder, but it is a new way to think its own business model having a long-lasting vision instead of short-term profit needs.

Finally, the attention for social and environmental impacts of business requires also new professional skills and the labor market should train directors and managers with accounting background, but who are also able to face the challenge of new sustainable business models.

Funding: This research received no external funding.

Conflicts of Interest: The author declares no conflict of interest.

\section{Appendix A}

Table A1. Companies Analyzed in the Research.

\begin{tabular}{cccccc}
\hline Company (FTSE MIB) & NACE & Company (STAR) & NACE & Company (STAR) & NACE \\
\hline A2a & 35.11 & Acotel & 61.90 & Isagro & 20.20 \\
Amplifon & 35.20 & Aeffe & 14.13 & La Doria & 10.39 \\
Atlantia & 52.29 & Aeroporto BO & 52.23 & Landi Renzo & 47.78 \\
Azimut Holding & 21.20 & Amplifon & 32.50 & Marr & 46.39 \\
Banco Bpm & 64.19 & Aquafil & 74.90 & Massimo Zanetti & 10.83 \\
\hline
\end{tabular}


Table A1. Cont.

\begin{tabular}{|c|c|c|c|c|c|}
\hline Company (FTSE MIB) & NACE & Company (STAR) & NACE & Company (STAR) & NACE \\
\hline Bper Banca & 64.19 & Ascopiave & 35.22 & Mondadori & 58.14 \\
\hline Buzzi Unicem & 23.51 & Avio & 84.12 & Mondo TV & 59.11 \\
\hline Cnh Industrial & 28.30 & $\mathrm{~B} \& \mathrm{C}$ & 26.40 & Mutuionline & 64.20 \\
\hline Diasorin & 21.20 & Finnat & 64.19 & Openjobmetis & 78.10 \\
\hline Enel & 35.11 & Ifis & 64.19 & Panaria group & 23.31 \\
\hline Eni & 06.10 & Sistema & 64.19 & Piovan & 28.29 \\
\hline Exor & 64.20 & $\mathrm{Be}$ & 62.09 & Poligrafica, S.Faustino & 18.12 \\
\hline Ferrari & 29.10 & Biesse & 28.99 & Prima industrie & 28.49 \\
\hline Fiat Chrysler Automobiles & 29.10 & Cairo & 73.11 & Reno de Medici & 17.12 \\
\hline Finecobank & 64.19 & Carel & 28.25 & Reply & 62.09 \\
\hline Generali & 64.19 & Cellular line & 64.20 & Sabaf & 27.51 \\
\hline Hera & 35.13 & Cembre & 27.12 & Saes Getters & 26.51 \\
\hline Intesa Sanpaolo & 64.19 & Cementir & 23.51 & Servizi Italia & 39.00 \\
\hline Italgas & 64.20 & Centrale latte & 10.51 & Sesa & 94.99 \\
\hline Juventus Football Club & 93.12 & Datalogic & 26.11 & Sogefi & 23.32 \\
\hline Leonardo & 30.30 & Dea capital & 64.92 & Tamburi & 66.19 \\
\hline Mediobanca & 64.19 & Digital Bros & 93.29 & Tesmec & 28.99 \\
\hline Moncler & 14.19 & El.En & 27.90 & Tinexta & 70.22 \\
\hline Nexi & 66.19 & Elica & 27.51 & Txt & 62.014 \\
\hline Pirelli \& C & 22.11 & Emak & 28.30 & Unieuro & 46.43 \\
\hline Poste Italiane & 64.99 & Eprice & 58.29 & Wiit & 62.01 \\
\hline Prysmian & 26.30 & Equita group & 84.24 & Zignago & 23.19 \\
\hline Recordati & 21.20 & Eprinet & 62.09 & & \\
\hline Saipem & 09.10 & Eurotech & 26.20 & & \\
\hline Salvatore Ferragamo & 15.20 & Exprivia & 62.01 & & \\
\hline Snam & 49.50 & Falck & 35.11 & & \\
\hline Stmicroelectronics & 26.11 & Fidia & 28.29 & & \\
\hline Telecom Italia & 61.90 & Gamenet & 93.29 & & \\
\hline Tenaris & 24.20 & Gedi Gruppo & 18.11 & & \\
\hline Terna & 35.11 & Gefran & 26.51 & & \\
\hline Ubi Banca & 64.19 & Giglio Group & 66.20 & & \\
\hline Unicredit & 64.19 & Guala & 22.22 & & \\
\hline Unipol & 65.00 & Interpump & 28.13 & & \\
\hline Unipolsai & 65.00 & Irce & 24.34 & & \\
\hline
\end{tabular}

\section{References}

1. Henry, L.H.; Buyl, T.; Jansen, R.J.C. Leading corporate sustainability: The role of top management team composition for triple bottom line performance. Bus. Strategy Environ. 2019, 28, 173-184. [CrossRef]

2. Zhang, J.Q.; Zhu, H.; Ding, H. Board Composition and Corporate Social Responsibility: An Empirical Investigation in the Post Sarbanes-Oxley Era. J. Bus. Ethics 2013, 114, 381-392. [CrossRef]

3. Fama, E.F. Agency Problems and the Theory of the Firm. J. Polit. Econ. 1980, 88, 288-307. [CrossRef]

4. Jensen, M.C.; Meckling, W. Theory of the firm: Managerial behaviour, agency costs and ownership structure. J. Financ. Econ. 1976, 3, 305-360. [CrossRef]

5. Daily, C.M.; Dalton, D.R.; Cannella, A.A. Corporate Governance: Decades of Dialogue and Data. Acad. Manag. Rev. 2003, 28, 371-382. [CrossRef]

6. Freeman, R.E. Strategic Management: A Stakeholder Approach; Pitman: Charlestown, MA, USA, 1984.

7. Rusconi, G. Ethical Firm System and Stakeholder Management Theories: A Possible Convergence. Eur. Manag. Rev. 2019, 16, 147-166. [CrossRef]

8. Elkington, J. Cannibals with Forks: The Triple Bottom Line of 21st Century Business; New Society: Gabriola Island, GA, Canada, 1998.

9. Gennari, F.; Salvioni, D.M. CSR committees on boards: The impact of the external country level factors. J. Manag. Gov. 2019, 23, 759-785. [CrossRef] 
10. Cosma, S.; Mastroleo, G.; Schwizer, P. Assessing corporate governance quality: Substance over form. J. Manag. Gov. 2018, 2, 457-493. [CrossRef]

11. He, L.; Yang, R.; He, Y. Does social exchange relationship impair audit committee effectiveness? J. Manag. Gov. 2018, 2, 219-249. [CrossRef]

12. OECD. G20/OECD Principles of Corporate Governance; OECD Publishing: Paris, France, 2015.

13. Burke, J.J.; Hoitash, R.; Hoitash, U. The Heterogeneity of Board-Level Sustainability Committees and Corporate Social Performance. J. Bus. Ethics 2019, 154, 1-26. [CrossRef]

14. Porter, M.; Kramer, M. Creating shared value. Harv. Bus. Rev. 2011, 89, 62-77.

15. Gabrielsson, J.; Huse, M. Context, Behavior, and Evolution: Challenges in Research on Boards and Governance. Int. Stud. Manag. Organ. 2004, 34,11-36. [CrossRef]

16. Kakabadse, A.P.; Kakabadse, N.K. CSR in Practice: Delving Deep; Palgrave MacMillan: London, UK, 2007.

17. Mahoney, L.S.; Thorne, L. Corporate Social Responsibility and Long-term Compensation: Evidence from Canada. J. Bus. Ethics 2005, 57, 241-253. [CrossRef]

18. Mason, C.; Simmons, J. Embedding corporate social responsibility in corporate governance: A stakeholder system approach. J. Bus. Ethics 2014, 119, 77-86. [CrossRef]

19. Salvioni, D.M.; Gennari, F.; Bosetti, L. Sustainability and Convergence: The Future of Corporate Governance Systems? Sustainability 2016, 8, 1203. [CrossRef]

20. Godos-Díez, J.L.; Cabeza-García, L.; Alonso-Martínez, D.; Fernández-Gago, R. Factors influencing board of directors' decision-making process as determinants of CSR engagement. Rev. Manag. Sci. 2018, 12, 229-253. [CrossRef]

21. Jo, H.; Harjoto, M.A. The Causal Effect of Corporate Governance on Corporate Social Responsibility. J. Bus. Ethics 2012, 106, 53-72. [CrossRef]

22. Konadu, R. Gender Diversity Impact on Corporate Social Responsibility (CSR) and Greenhouse Gas Emissions in the UK. Econ. Bus. Rev. 2017, 3, 127-148. [CrossRef]

23. Mallin, C.; Michelon, G. Monitoring Intensity and Stakeholders' Orientation: How Does Governance Affect Social and Environmental Disclosure? J. Bus. Ethics 2013, 114, 29-43. [CrossRef]

24. Rodrigue, M.; Magnan, M.; Cho, C.H. Is environmental governance substantive or symbolic? An empirical investigation. J. Bus. Ethics 2013, 114, 107-129. [CrossRef]

25. Walls, J.L.; Berrone, P.; Phan, P.H. Corporate governance and environmental performance: Is there really a link? Strateg. Manag. J. 2012, 33, 885-913. [CrossRef]

26. Cucari, N.; Esposito De Falco, S.; Orlando, B. Diversity of Board of Directors and Environmental Social Governance. Corp. Soc. Responsib. Environ. Manag. 2018, 25, 250-266. [CrossRef]

27. García-Sánchez, I.M.; Gómez-Miranda, M.E.; David, F.; Rodríguez-Ariza, L. Board independence and GRI-IFC Performance Standards: The mediating effect of the CSR committee. J. Clean. Prod. 2019, 225, 554-562. [CrossRef]

28. DiMaggio, P.J.; Powell, W.W. The iron cage revisited: Institutional isomorphism and collective rationality in organizational fields. Am. Sociol. Rev. 1983, 48, 147-160. [CrossRef]

29. Raynard, M.; Johnson, G.; Greenwood, R. Institutional theory and strategic management. In Strategic Management: A Multiple-Perspective Approach; Jenkins, M., Ambrosini, V., Eds.; Palgrave: London, UK, 2015.

30. Scott, W.R. Institutions and Organizations: Ideas and Interests; Sage Publications: Thousand Oaks, CA, USA, 2008.

31. Suchman, M.C. Managing Legitimacy: Strategic and Institutional Approaches. Acad. Manag. J. 1995, 20, 571-610.

32. Barney, J.B. Firm Resources and Sustained Competitive Advantage. J. Manag. 1991, 17, 99-120. [CrossRef]

33. Eisenhardt, K.M.; Martin, J.A. Dynamic Capabilities: What Are They? Strateg. Manag. J. 2000, 21, $1105-1121$. [CrossRef]

34. Grant, R. The Resource-Based Theory of Competitive Advantage: Implications for Strategy Formulation. Calif. Manag. Rev. 1991, 33, 114-135. [CrossRef]

35. Anderson, G.; Orsagh, M. The Corporate Governance Risk. Electr. Perspect. 2004, $29,68$.

36. Arjoon, S. Corporate Governance: An Ethical Perspective. J. Bus. Ethics 2005, 61, 343-352. [CrossRef]

37. Bathala, C.T.; Rao, R.P. The Determinants of Board Composition: An Agency Theory Perspective. Manag. Decis. Econ. 1995, 16, 59-69. [CrossRef] 
38. Rao, K.; Tilt, C. Board Composition and Corporate Social Responsibility: The Role of Diversity, Gender, Strategy and Decision Making. J. Bus. Ethics 2016. [CrossRef]

39. Dobija, D. Exploring audit committee practices: Oversight of financial reporting and external auditors in Poland. J. Manag. Gov. 2015. [CrossRef]

40. He, X.; Pittman, J.A.; Rui, O.M.; Wu, D. Do Social ties between External Auditors and Audit Committee Members Affect Audit Quality? Account. Rev. 2017, 92, 61-87. [CrossRef]

41. Eccles, R.G.; Iannou, I.; Serafeim, G. The Impact of Corporate Sustainability on Organizational Processes and Performance. Manag. Sci. 2014, 6, 2835-2857. [CrossRef]

42. Deloitte \& Touche. The Social and Ethics Committee and the Management of the Ethics Performance of the Company; Deloitte \& Touche: Johannesburg, South Africa, 2014.

43. Goedhart, M.; Koller, T.; Wessels, D. The Real Business of Business; McKinsey on Finance: New York, NY, USA, 2015.

44. Salvioni, D.M.; Gennari, F. CSR, Sustainable Value Creation and Shareholder Relations, Symphonya. Emer. Issues Manag. 2017, 1, 36-49.

45. Purcell, T.V. The Ethics of Corporate Governance. Rev. Soc. Econ. 1982, 40, 360-370. [CrossRef]

46. Spence, M. Job Market Signaling. Q. J. Econ. 1973, 87, 355-374. [CrossRef]

47. Carmen-Pilar, M. The role of mutual funds in the sustainable energy sector. Bus. Strat. Environ. 2019, 28, 1107-1120.

48. Kassinis, G.; Vafeas, N. Corporate boards and outside stakeholders as determinants of environmental litigation. Strat. Manag. J. 2002, 23, 399-415. [CrossRef]

49. Kent, P.; Monem, R. What drives TBL reporting: Good governance or threat to legitimacy? Aust. Account. Rev. 2008, 18, 297-309. [CrossRef]

50. Michelon, G.; Parbonetti, A. The effect of corporate governance on sustainability disclosure. J. Manag. Gov. 2012, 16, 477-509. [CrossRef]

51. Amran, A.; Lee, S.P.; Devi, S.S. The influence of governance structure and strategic corporate social responsibility toward sustainability reporting quality. Bus. Strat. Environ. 2014, 23, 217-235. [CrossRef]

52. Helfaya, A.; Moussa, T. Do board's corporate social responsibility strategy and orientation influence environmental sustainability disclosure? UK Evidence. Bus. Strat. Environ. 2017. [CrossRef]

53. Mahmood, Z.; Kouser, R.; Ali, W.; Ahmad, Z.; Salman, T. Does corporate governance affect sustainability disclosure? A mixed methods study. Sustainability 2018, 10, 207. [CrossRef]

54. Baraibar-Diez, E.; Odriozola, M.D. CSR Committees and Their Effect on ESG Performance in UK, France, Germany, and Spain. Sustainability 2019, 11, 5077. [CrossRef]

55. Birindelli, G.; Dell'Atti, S.; Iannuzzi, A.P.; Savioli, M. Composition and Activity of the Board of Directors: Impact on ESG Performance in the Banking System. Sustainability 2018, 10, 4699. [CrossRef]

56. Dixon-Fowler, H.R.; Ellstrand, A.E.; Johnson, J.L. The Role of Board Environmental Committees in Corporate Environmental Performance. J. Bus. Ethics 2017, 40, 423-438. [CrossRef]

57. Eberhardt-Toth, E.; Caby, J.; Gendron, C.; Ramboarisata, L. Determinants of the presence of CSR committees within European boards of directors. Rev. Organ. Responsib. 2019, 14, 33-49. [CrossRef]

58. Liao, C.; Hsu, A.W. Common Membership and Effective Corporate Governance: Evidence from Audit and Compensation Committees. Corp. Gov. Int. Rev. 2013, 21, 79-92. [CrossRef]

59. Boivie, S.; Bednar, M.K.; Aguilera, R.V.; Andrus, J.L. Are Boards Designed to Fail? The Implausibility of Effective Board Monitoring. Acad. Manag. Ann. 2016, 10, 319-407. [CrossRef]

60. Kolev, K.D.; Wangrow, D.B.; Barker, V.L., III; Schepker, D.J. Board Committees in Corporate Governance: A Cross-Disciplinary Review and Agenda for the Future. J. Manag. Stud. 2019, 56, 1138-1196. [CrossRef]

61. Peters, G.F.; Romi, A.M. The Association between Sustainability Governance Characteristics and the Assurance of Corporate Sustainability Reports. Audit. J. Pract. Theory 2013, 34, 163-198. [CrossRef]

62. Chapple, L.L.; Chen, Z.; Zhang, Y. Sustainability Committee Effectiveness and CSR Assurance. 2017. Available online: https://ssrn.com/abstract=2967165 (accessed on 15 July 2019).

63. Macus, M. Board Capability; An Interactions Perspective on Boards of Directors and Firm Performance. Int. Stud. Manag. Organ. 2008, 38, 98-116. [CrossRef]

64. Miller, K.; Serafeim, G. Chief Sustainability Officers: Who Are They and What Do They Do? Leading Sustainable Change; Oxford University Press: Oxford, UK, 2014. 
65. Anderson, R.C.; Reeb, D.M. Board Composition: Balancing Family Influence in S\&P 500 Firms. Adm. Sci. Q. 2004, 49, 209-237.

66. Chavance, B. Formal and Informal Institutional Change: The Experience of Postsocialist Transformation. Eur. J. Comp. Econ. 2008, 5, 57-71.

67. Ghecham, M.A. Formal and Informal Institutional Constraints and the Performance of Firms in Developing Economies: The Case of Egypt. 2006. Available online: http://dx.doi.org/10.2139/ssrn.938099 (accessed on 15 July 2019).

68. North, D. Institutions, Institutional Change and Economic Performance; Cambridge University Press: London, UK, 1990.

69. Vigneau, L.; Humphreys, M.; Moon, J. How Do Firms Comply with International Sustainability Standards? Processes and Consequences of Adopting the Global Reporting Initiative. J. Bus. Ethics 2015, 131, 469-486. [CrossRef]

70. Galander, A.; Walgenbach, P.; Rost, K. A social norm perspective on corporate governance soft law. Corp. Gov. 2015, 15, 31-51. [CrossRef]

71. Balleisen, E.J.; Eisner, M. The Promise and Pitfalls of Co-Regulation: How Governments Can Draw on Private Governance for Public Purpose. In New Perspectives on Regulation; Moss, D., Cisternino, J., Eds.; Duke University: Cambridge, UK, 2009.

72. Haxhi, I.; Hans van Ees, H. Explaining diversity in the worldwide diffusion of codes of good governance. J. Int. Bus. Stud. 2010, 41, 710-726. [CrossRef]

73. Miras-Rodriguez, M.; Di Pietra, R. Corporate Governance mechanisms as drivers that enhance the credibility and usefulness of CSR disclosure. J. Manag. Gov. 2018, 3, 565-588. [CrossRef]

74. Jo, H.; Na, H. Does CSR Reduce Firm Risk? Evidence from Controversial Industry Sectors. J. Bus. Ethics 2012, 110, 441-456. [CrossRef]

75. Bebbington, J.; Larrinaga, C.; Mariano Moneva, J.M. Corporate social reporting and reputation risk management. Account. Audit. Account. J. 2008, 21, 371-374. [CrossRef]

76. Unerman, J. Strategic reputation, risk management and corporate social responsibility reporting. Account. Audit. Account. J. 2008, 21, 362-364. [CrossRef]

77. Jackson, G.; Apostolakou, A. Corporate social responsibility in Western Europe: An institutional mirror or substitute? J. Bus. Ethics 2010, 94, 371-394. [CrossRef]

78. Young, S.; Marais, M. A Multi-level Perspective of CSR Reporting: The Implications of National Institutions and Industry Risk Characteristics. Corp. Gov. 2012, 20, 432-450. [CrossRef]

79. Black, L. Your social license to operate: Risk protection through community development. Gov. Dir. 2014, 66, 12.

80. Godfrey, P.C.; Merrill, C.; Hansen, J. The relation between corporate social responsibility and shareholder value: An empirical test of the risk management hypothesis. Strat. Manag. J. 2009, 30, 425-445. [CrossRef]

81. Salama, A.; Anderson, K.; Toms, J.S. Does community and environmental responsibility affect firm risk: Evidence from UK panel data 1994-2006. Bus. Ethics Eur. Rev. 2011, 20, 192-204. [CrossRef]

82. Liebenberg, A.P.; Hoyt, R.E. The Determinants of Enterprise Risk Management: Evidence From the Appointment of Chief Risk Officers. Risk Manag. Insur. Rev. 2003, 6, 37-53. [CrossRef]

83. Haubenstock, M. Organizing a Financial Institution to Deliver Enterprise-Wide Risk Management. J. Lend. Credit Risk Manag. 1999, 1, 46-52.

84. Alshehhi, A.; Nobanee, H.; Khare, N. The Impact of Sustainability Practices on Corporate Financial Performance: Literature Trends and Future Research Potential. Sustainability 2018, 10, 494. [CrossRef]

85. Hollos, D.; Blome, C.; Foerstl, K. Does sustainable supplier co-operation affect performance? Examining implications for the triple bottom line. Int. J. Prod. Res. 2012, 50, 2968-2986. [CrossRef]

86. Horváthová, E. Does environmental performance affect financial performance? A meta-analysis. Ecol. Econ. 2010, 70, 52-59. [CrossRef]

87. Samy, M.; Odemilin, G.; Bampton, R. Corporate social responsibility: A strategy for sustainable business success. An analysis of 20 selected British companies. Corp. Gov. 2010, 10, 203-221. [CrossRef]

88. Al-Khazali, O.M.; Zoubi, T.A. Empirical Testing of Different Alternative Proxy Measures For Firm Size. J. Appl. Bus. Res. 2005, 21, 79-90. [CrossRef]

89. Salamon, G.; Dhalival, D. Company Size and Financial Disclosure Requirements With Evidence from the Segmental Reporting Issue. J. Bus. Financ. Account. 1980, 7, 555-568. [CrossRef] 
90. Fifka, M.S. Corporate Responsibility Reporting and its Determinants in Comparative Perspective-A Review of the Empirical Literature and a Meta-analysis. Bus. Strat. Environ. 2013, 22, 1-35. [CrossRef]

91. Brammer, S.; Millington, A. Firm sixe, organizational visibility and corporate philanthropy: An empirical analysis. Bus. Ethics 2006, 15, 6-18. [CrossRef]

92. Salvioni, D.M.; Gennari, F. Corporate Governance, ownership and sustainability. Corp. Ownersh. Control 2016, 13, 606-614. [CrossRef]

93. Villalonga, B. The impact of ownership on building sustainable and responsible businesses. J. Br. Acad. 2018, 6, 375-403. [CrossRef]

94. Bacon, N.; Wright, M.; Ball, R.; Meuleman, M. Private Equity, HRM, and employment. Acad. Manag. Perspect. 2013, 27, 7-21. [CrossRef]

95. Bushee, B. The influence of institutional investors on myopic R\&D investment behaviour. Account. Rev. 1998, 73, 305-333.

96. Bushee, B. Identifying and attracting the 'right' investors: Evidence on the behaviour of institutional investors. J. Appl. Corp. Finance 2004, 26, 28-35. [CrossRef]

97. Hoskisson, R.E.; Hitt, M.A.; Johnson, R.A.; Grossman, W. Conflicting voices: The effects of institutional ownership heterogeneity and internal governance on corporate innovation strategies. Acad. Manag. J. 2017, 45, 697-716.

98. Miller, D.; Wright, M.; Le Breton-Miller, I.; Scholes, L. Resources and innovation in family businesses: The Janus-face of socioemotional preferences. Calif. Manag. Rev. 2015, 58, 20-40. [CrossRef]

99. Das, S.; Dixon, R.; Michael, A. Corporate social responsibility reporting: A longitudinal study of listed banking companies in Bangladesh. World Rev. Bus. Res. 2015, 5, 130-154.

100. Haniffa, R.; Cooke, T. The impact of culture and governance on corporate social reporting. J. Account. Public Policy 2005, 24, 391-430. [CrossRef]

101. Khan, M. The effect of corporate governance elements on corporate social responsibility (CSR) reporting: Empirical evidence from private commercial banks of Bangladesh. Int. J. Law Manag. 2010, 52, 82-109. [CrossRef]

102. Oh, W.; Chang, Y.; Martynov, A. The effect of ownership structure on corporate social responsibility: Empirical evidence from Korea. J. Bus. Ethics 2011, 104, 283-297. [CrossRef]

103. Soliman, M.; Ragab, A. Audit committee effectiveness, audit quality and earnings management: An empirical study of the listed companies in Egypt. Res. J. Finance Account. 2012, 5, 155-166. [CrossRef]

104. Garas, S.; ElMassah, S. Corporate governance and corporate social responsibility disclosures. The case of GCC countries. Crit. Perspect. Int. Bus. 2018, 14, 2-26. [CrossRef]

105. Faller, C.M.; Zu Knyphausen-Aufseß, D. Does equity ownership matter for corporate social responsibility? A literature review of theories and recent empirical findings. J. Bus. Ethics 2018, 150, 15-40. [CrossRef]

106. Block, J.H.; Wagner, M. The Effect of Family Ownership on Different Dimensions of Corporate Social Responsibility: Evidence from Large US Firms. Bus. Strat. Environ. 2013, 23, 475-492. [CrossRef]

107. Rees, W.; Rodionova, T. The Influence of Family Ownership on Corporate Social Responsibility: An International Analysis of Publicly Listed Companies. Corp. Gov. 2014, 23, 184-202. [CrossRef]

108. Darus, F.; Hamzah, E.; Yusoff, H. CSR web reporting: The influence of ownership structure and mimetic isomorphism. Econ. Financ. 2013, 7, 236-242. [CrossRef]

109. Rudyanto, A. State Ownership, Family Ownership, and Sustainability Report Quality: The Moderating Role of Board Effectiveness. Account. Finance Rev. 2017, 2, 15-25.

110. Alda, M. Corporate sustainability and institutional shareholders: The pressure of social responsible pension funds on environmental firm practices. Bus. Strat. Environ. 2019, 28, 929-1284. [CrossRef]

111. Berg, B.L. Qualitative Research Methods for the Social Sciences; Allyn and Bacon: Boston, MA, USA, 2001.

112. Harris, H. Content Analysis of Secondary Data: A Study of Courage in Managerial Decision Making. J. Bus. Ethics 2001, 34, 191-208. [CrossRef]

113. Hair, J.F.; Black, W.C.; Babin, B.J.; Anderson, R.E. Multivariate Data Analysis. A Global Perspective; Pearson Education: Hoboken, NJ, USA, 2010.

114. Chizema, A. Institutions and voluntary compliance: The disclosure of individual executive paying Germany. Corp. Gov. Int. Rev. 2008, 16, 359-374. [CrossRef]

115. OECD. Risk Management and Corporate Governance; OECD Publishing: Paris, France, 2014. 
116. Patten, D.M. Exposure, Legitimacy, and Social Disclosure. J. Account. Public Policy 1991, 10, $297-308$. [CrossRef]

117. Prencipe, A. Proprietary Costs and Determinants of Voluntary Segment Disclosure: Evidence from Italian Listed Companies. Eur. Account. Rev. 2004, 13, 319-340. [CrossRef]

118. Cormier, D.; Magnan, M.; Van Velthoven, B. Environmental disclosure quality in large German companies: Economic incentives, public pressures or institutional conditions? Eur. Account. Rev. 2005, 14, 3-39. [CrossRef]

119. Secchi, D. The Italian Experience in Social Reporting: An Empirical Analysis. Corp. Soc. Responsib. Environ. Manag. 2006, 13, 135-149. [CrossRef]

120. Tagesson, T.; Blank, V.; Broberg, P.; Collin, S.O. What explains the extent and content of social and environmental disclosures on corporate websites: A study of social and environmental reporting in Swedish listed corporations. Corp. Soc. Responsib. Environ. Manag. 2009, 16, 352-364. [CrossRef]

121. Green, S. Understanding Corporate Culture and Its Relation to Strategy. Int. Stud. Manag. Organ. 1988, 18, 6-28. [CrossRef]

122. Salvioni, D.M. Intangible Assets and Internal Controls in Global Companies, Symphonya. Emerg. Issues Manag. 2010, 1, 39-51.

(C) 2019 by the author. Licensee MDPI, Basel, Switzerland. This article is an open access article distributed under the terms and conditions of the Creative Commons Attribution (CC BY) license (http://creativecommons.org/licenses/by/4.0/). 